JUSTYNA SARNOWSKA*

SWPS University

DOMINIKA WINOGRODZKA**

SWPS University

PAULA PUSTUŁKA***

SWPS University

https://doi.org/10.26485/PS/2018/67.3/5

\title{
THE CHANGING MEANINGS OF WORK AMONG UNIVERSITY-EDUCATED YOUNG ADULTS FROM A TEMPORAL PERSPECTIVE
}

\begin{abstract}
The article discusses the processes of meaning-making which are connected to the significance of work/employment as it intersects with the passage of time. We focus on the narratives of young people (aged 19-34) with a university education at different stages of entering adulthood. Drawing on research linked to education-to-work transitions, we rely on the notion of flexible social time [Adam 1998] to present how individuals subjectively construct breaks and turning points in their biographies. It is argued that the passage of time alters the experience and evaluation of events on the labour market. Based on empirical material from the project entitled Education-todomestic and-foreign labour market transitions of youth: The role of locality, peer group and new media, we discuss three stages tied to varied meanings of work, from late adolescence to adulthood. In particular, we give voice to the interviewees who shared their reflections about: (1) working during high-school, (2) combining university education with employment, and (3) transitioning from education to work, and later career trajectories until
\end{abstract}

* Dr, Youth Research Center; e-mail: jsarnowska@swps.edu.pl

** Mgr, Youth Research Center; e-mail: dwinogrodzka@swps.edu.pl

*** Dr, Youth Research Center; e-mail: ppustulka@swps.edu.pl 
their early 30 s. The article sheds light on the issue of labour market stability as distinctively constructed at subsequent life-stages.

Keywords: young adults, meanings of work, transition to adulthood, life-course, temporal theory, labour market

\section{INTRODUCTION: EXAMINING WORK FROM A TEMPORAL ANGLE}

This work is situated in the context of a profound shift that has marked the education-to-work transitions of the generation of Poles born from 1982 to 1995, meaning those currently in their 20 s and early 30 s. When compared with their parents, they no longer experience the (communist) government's intervention into their personal choices, which used to mean more homogenisation of the life-cycle for previous generations [Settersten 2004; Hofmeister 2013]. Not only were the earlier individual biographies quite consistent across a generation, but this critical mass of similarities made particular sequences of events and their corresponding temporal frameworks a social norm in Poland. This means that current 20-30-year-olds grew up watching a specific set of social expectations about markers and timelines of different life-phases [Kohli 2007]. Consequently, they have been socialised into understanding when a given life-stage should begin and end, as well as what the appropriate order of socially accepted events is from a temporal stance [Adam 1998].

In recent years, however, the normative model of a life-course [Kohli 2007] can no longer be universally applied. It was replaced with the idea of flexibilisation [Kovacheva 2001] of youth transitions in Central and Eastern Europe, as well as more broadly [Holdsworth, Morgan 2005]. Since the 1989 transformation in Poland, we have observed a deconstruction of the earlier, temporally more-defined pathways. Importantly, the profound change affects not only one aspect of an individual's biography, but rather it encompasses all aspects, spanning (longer) education, (more fragmented) employment history and (alternative forms of) family life [Holdsworth, Morgan 2005]. In the risk society of the reflexive "late modernity" [Beck, Giddens, Lash 1994], the life-cycle is no longer sequential or pre-determined. Instead, we see transitions that are occurring differently on personal timelines and are de-standardised, fractured and generally much more diverse [Furlong, Cartmel 2006; Wyn, Dwyer 2000; Hodkinson, Sparkes, Hodkinson 2013]. 
The heterogeneity linked to flexibilisation [Kovacheva 2001; Wyn, Dwyer 2002; Furlong, Cartmel 2006] is now the most common trait of educational and professional careers for people born in the 1980s and 1990s. In that sense, Polish society has moved from a dominant model of a "compressed" transition, in which people born in the first half of the $20^{\text {th }}$ century experienced a prompt and uncomplicated sequence of moving from education to employment and family, to a new setup [see also Sarnowska 2016]. The transitions are currently diffuse, "spanning longer timeframes, blurry and multifarious" [Piróg 2016]. It is much less clear when an actual switch from one phase to another takes place and whether it is even a definite, directional progression [see also Holdsworth, Morgan 2005].

With the dawn of sequential, orderly biographies, different ways of looking at transitions need to be conceived. The objective of this article is to demonstrate that "adding time into the mix" [Neale 2013] can be a fruitful way to elucidate the nuances of what one of the key aspects of transitions - namely work - means for young people as time goes by. With the temporal orientation and a life-course perspective, we discuss employment narratives of contemporary Polish youth over the course of their adolescence and early-to-mid adulthood, focusing on those with university education. We specifically rely on Adam's [1998] notion of flexible time, which lets us move beyond the numerical calendar of dates and deadlines, instead, assigning a value to how time is perceived independently of its measurements in certain social settings and life phases. Biographical meaning-making is effectuated by the interviewees who understand phases and transitions not as singular moments favoured by former generations, but rather as dynamic, flexible processes. Both the definitions of work and the factors that make a job serious in the eyes of highly-educated respondents are never cut-and-dried but permanently unstable and ever-evolving [Wyn, Dwyer 2000; Furlong, Cartmel 2006; Kohli 2007; Côté, Bynner 2008].

In this article we are seeking to answer two key questions: (1) When and why does work become serious for young people? and (2) What is the role of time in the changing employment narratives among university-educated adults in Poland? In the following sections, we first present the context in which our interviewees operate, specifically by discussing earlier research on the three stages of working during adolescence, combining university education with work, and the labour market experiences following the completion of a degree. After providing a short note on the data and methods, we move on to the findings, which are structurally organised to reflect the above three phases of a young person's life-cycle. Discussions and conclusions follow. 


\section{WORKING DURING THE TEENAGE YEARS}

Although sociological depictions of subsequent generations of young people originally tended to focus more on the problematic aspects of youth culture, especially delinquency and deviance, contemporary youth studies place an emphasis on the carefree, "coming of age" period, full of experimentation, as a necessary phase of emerging adulthood in the modern world [Arnett 2011].

Regarding the employment of adolescents, studies usually point to both the significant costs and the considerable gains [Marsh 1991; Staff, Mortimer 2007] of working during high-school. In particular, the authors show the role-conflicts among high school job holders who might benefit from early responsibility and character building yet, just as often, may withdraw from academia and jeopardise their educational success. As the two concurrent explanations were explored, it was ultimately concluded that the negative and positive implications of adolescent work were clearly dependent on the extent of the early employment. The involvement of youth in economic activity has two long-term consequences: if early work experience is overly intense, young people are pulled away from academic orientation, and this involvement negatively affects their wage attainment [Staff, Mortimer 2007]. Conversely, working towards a clear goal of having enough money for university indeed translates to a greater probability of following-up with a tertiary degree and lowered attrition [Marsh 1991].

In Poland, it is becoming increasingly common to have early work experiences, though these are mostly seasonal in nature [CBOS 2016]. Youth work in Poland is gendered (in the sense of boys being more likely to work) and class-dependent, as pupils in vocational programs and those originating from low-income households tend to work more often [Kasparek, Magierowski 2014]. According to survey data, $59 \%$ of secondary school students worked during summer holidays to finance their personal expenses, and slightly more than 1 in 3 teenagers had a part-time job during the school year [CBOS 2016].

\section{COMBINING UNIVERSITY EDUCATION WITH WORK}

Researchers consistently demonstrated that rolling back the welfare states in Europe has spill-over effects on the increasing numbers of university students needing to work while studying. While term-time work was rarely investigated during the 1990s, because it was a relatively marginal occurrence [Metcalf 2003], it is becoming the norm in recent years and encompasses both registered and informal work [Geel, Backes-Gellner 2012]. 
Following this trend, half of all Polish secondary school graduates pursuing degrees indicate that they want to work while studying [CBOS 2016]. However, cross-country differences hinge upon the temporal dimension, i.e. the amount of time dedicated to work. For example, while Danish or Dutch students work 13 and 16 hours per week, respectively, the work of their Polish counterpart amounts to nearly a full-time (FT) post at 35 hours weekly.

Nearly $40 \%$ of Polish FT students worked in the previous year, and the vast majority had non-standard job arrangements. While two-thirds of the students (particularly women) completed internships, only one in five students had a standard job contract. The main motivations behind the decision to combine education and work were gauged and, as expected, reflected the economic strain and the need to establish financial independence (at least partially) from parents [Kasparek, Magierowski 2014].

As with high-school employment, the arguments for and against simultaneously fulfilling the two competing roles of worker and student have been raised. Negative implications of university term-time work were linked to lower academic success, increased dropout rates, and the limited social engagement of the working students. The positive aspects pertained to gaining valuable professional experience early on, although the main concern remained that very few students (ca. 10\% across various studies) had jobs in any way linked to their field of study [Metcalf 2003]. This finding was replicated in the Polish data [Kasparek, Magierowski 2014] as the majority of work experiences were disconnected from the pathway envisioned regarding the degree/specialisation. Qualitative research nevertheless demonstrates social pressures on people moving towards having a stable job linked to their degree as graduation approaches [Sarnowska, Grabowska 2018].

Summing up, it appears that the "study first then work" model is typical for Polish FT students from middle-class backgrounds, who use summer breaks to gain experience or supplement their income. Conversely, the "study while working" model tends to characterise those in PT and extra-mural programs, who often come from less privileged backgrounds [Piróg 2016:15].

\section{YOUNG PEOPLE AND THE POLISH LABOUR MARKET}

The transition from education to work has been the subject of a considerable number of analyses, both statistical (e.g. the time it takes for a graduate to get a job), and ethnographic. The latter explore the challenges that university degree holders experience on the precarious European labour markets in connection with 
skill-mismatches and the demands posed by a digital workforce [e.g. Furlong, Cartmel 2006; Allen, De Weert 2007; Salas-Velasco 2007].

A growing number of people in precarious forms of employment has been noted in Poland in recent decades. Specifically, those with non-standard job contracts increased from 5\% in 2000 to $30 \%$ in 2015. Young cohorts (people aged 15 to 24 ) are even more vulnerable as $75 \%$ had such jobs by 2015 [Eurostat, LFS n.d.]. Poland stands out among other EU countries, and the proportion of those employed on a legally-limiting basis is double the European average [ $28 \%$ vs 14\%; ETUI 2015]. This happens while Poles are increasingly better-educated, with $44.6 \%$ in the $30-34$ age-cohort holding university degrees. The rise of precarious employment happens concurrently with the growing rate of Poles with higher education, which reached $25.2 \%$ in 2016 for the general population and stands at $44.6 \%$ for the cohort presumed to have finished education [those aged 30-34; GUS 2017].

Research monitoring the pathways of graduates shows that they find their first job within ca. 3 months of obtaining an M.A. but need a further 6 months to find employment with a standard job contract ${ }^{1}$. The problem with the data is that it rarely distinguishes those who already worked while studying, even though this is a growing segment of graduates [Jelonek 2015]. Kiersztyn [2015] underlines that young people with higher education are increasingly likely to have non-standard contracts for extended periods, and Jelonek [2015] defines a "delayed highereducation gain", which means that subsequent cohorts need more and more time to find work that actually corresponds to both the level and the specialisation of their degrees. Jelonek shows that the first job after completing university tends to be at a low-level with little prestige and limited remuneration. Consequently, it becomes a transitory experience which is rarely satisfying. Those who begin their professional pathway at entry-level positions appear to believe in career advancement and - as the data show - indeed progress on the professional ladder in later years.

As noted, the situation in Poland mirrors some of the broader patterns found in Europe [Allen, De Weert 2007; Salas-Velasco 2007]. While one reason behind the blurriness of transitions [Piróg 2016] is the uncertainty linked to flexible labour and precarious forms of employment [Wyn, Dwyer 2000; Kovacheva 2001],

In this work, we refer to the Polish context in which the distinction is made between civillaw contracts and standard contracts of employment (PL: umowa o prace) regulated by the Labour Code. The former category includes contracts for specific work (PL: umowa o dzieto), contracts of mandate (PL: umowa zlecenia) and, usually also temporary, fixed-term contracts. These are deemed "non-standard" forms of work and colloquially called "junk contracts" (PL: umowy śmieciowe). 
another rationale points to the overlapping student and worker roles discussed in the previous section. Studying while working full-time, and working (part-time or seasonally) during studies understandably makes it more difficult for an individual to pinpoint the actual transition on a time axis. This explains the main argument we raise in this work: the meaning of work is subject to redefinitions on multiple occasions as the three phases of work in high-school, working during university and working after graduation life-cycle phases develop [see also Neale 2018].

\section{DATA AND METHODS}

This article draws on empirical material collected for the project Education-to-domestic and-foreign labour market transitions of youth: The role of locality, peer group and new media ${ }^{2}$. As a wide-ranging study reliant on the Qualitative Longitudinal Study (QLS) methods [Neale 2018], it concentrates on the education and employment pathways of young Polish migrants and non-migrants. The project is rooted in the QLS principle of "walking alongside" the research participants and gathers retrospective, current and prospective data on trajectories and biographies with a temporal lens [Grabowska et al. 2017; Pustułka, Juchniewicz, Grabowska 2017]. While research to date tended to focus on migrants either from villages or large cities, the participants of the study originate from three medium-sized towns in different parts of Poland. All towns are county capitals with strong migration cultures, a high mean age of the residents, a good network of secondary schooling, and Special Economic Zones. Migrant informants were generally recruited first, followed by members of their peer networks. The contacts came from the researchers' networks, online advertisements and later also snowballing [Grabowska et al. 2017: 20-21].

For the purpose of this article, a selection of interviews from Waves 1 and 2 of the study, completed in 2016 and 2018, was examined. Specifically, we chose to draw a sub-sample of 85 interviewees with higher education, as such a selection enables observation of a longer educational cycle, i.e., from early adolescence to adulthood, which envelops the three stages of change around employment. This was a theoretical sampling approach, dictated by the analytical focus of looking at the meaning of work across three subsequent stages of the life-cycle,

2 The project, with the full title Education-to-domestic and-foreign labour market transitions of youth: The role of locality, peer group and new media (abbreviated to Peer-Groups \& Migration), is funded by the Polish National Science Center under the Sonata Bis Project Contract No. 2015/18/E/HS6/00147. 
inclusive of experience during the pursuit of university degrees and the resulting transition from education to work in this context. This corresponds to the key data collection (qualitative interviewing) which provides the means to confront past, present and future planes [or timescapes; Neale 2018].

While the research participants were recruited as members of peer groups studied in the larger project, we chose individual interviewees as a more fitting unit of analysis here. Regarding the method, the QLS data for both Wave 1 and Wave 2 was collected through individual in-depth interviews (IDIs). The interview guides contained explicit question-blocks on educational trajectory and employment history, including probes that called for evaluations of work experiences (e.g. direct questions about the most important job, stability, etc). The analyses presented in this article were conducted on the dataset extracted from the Atlas.ti software on the basis of preselected thematic codes, ultimately reaching saturation. For the purpose of this article, we extracted and analysed Wave 1's material coded under "combining education with work", "entering labour market", "first serious job", "most important job", "least important job", and "internship". Besides this selection, for Wave 2, we also analysed interviews with reference to "stability on the labour market" and "uncertainty". It should be added that the project adheres to all best practices around data handling and confidentiality regarding ethics, so the quotations presented here have had all identifying details altered to preserve the anonymity of the respondents [see also Neale 2013; Neale 2018].

In terms of the respondents' characteristics, it should be noted that the holders of university degrees interviewed for the project were born between 1982 and 1995, signifying those in the 21-34 age group at the time of the first interview. Among the 85 interviewees, 27 were men, and 58 were women ${ }^{3}$. The majority (57) progressed to a Master's degree (MA or MSc), one had completed a $\mathrm{PhD}$, and the rest (27) had Bachelor and Engineering degrees. Importantly, while the majority worked full-time, some were in (or had returned to) education, i.e., they continued to pursue MAs, MScs, $\mathrm{PhDs}$ and other postgraduate qualifications. The respondents predominantly studied in Warsaw, Kraków and Gdańsk, but their majors and programs varied greatly.

3 This reflects the representation of sexes in the Polish graduates' population, which has a 64-to-36 female to male ratio (GUS 2018: 2). Women are more willing to participate in research, especially in-depth interviews (Letherby 2003:100-101). 


\section{HIGH-SCHOOL: PART-TIME WORK DURING VACATION AND FOR A VACATION BUDGET}

In accordance with common sense expectations, the motivations for working during secondary schooling are predominantly economic. In particular, for the interviewees from towns located not too far away from tourist attractions, it was quite typical to engage in seasonal work during holidays. This situates our respondents in the broader picture of young people in Poland presented above [CBOS 2016], as working to acquire funds for their owns needs, especially in relation to leisure, was common:

In high-school, you start making friends. For the first time you travel without your parents, and you need money for that. My father was out of the picture, and I felt ashamed of being so big and taking money from my mum. I think 5 out of the $30 \mathrm{pu}$ pils in my class worked. (...) The others did not taint themselves with work until university graduation. Not everyone gets [money] from their parents. Work broadens your horizons. (Alan/'92)

Among the young people who became partially responsible for households through high-school employment, it was predominantly males from single-mother households who felt embarrassed by being a burden. The above quotation indicates an accelerated process of entering adulthood.

One of the interesting themes is the attitude that the interviewees have towards high-school work from the current perspective of early-adulthood. Some belittle this experience to the point of not mentioning it, while others described it as banal and meaningless:

What was your first job? Seasonal work [at a resort]. It was not important; its goal was strictly to earn money. (...) It was a moment in my life which simply somehow passed and disappeared. It neither made an impression on me nor did I meet [important] people there. (Olga/'92)

For Olga, the entire high-school experience was a "blip" that she wished to subvert, and working was not a goal in itself but rather the means to a (financial) end. It seems that working (or any other activity other than learning) during highschool was not a turning point for Olga, who perceives this period as something that had no significant bearing for her path. Trivialising the role of work during high-school was also common when the picture of the past did not have anything to do with the present. For example, people who now hold prestigious and responsible posts would not be too inclined to reveal that they bussed tables or 
distributed flyers. In such contexts, earning money in high-school was not seen as work but rather just an activity that a respondent happened to undertake:

Nothing to boast about. Usually just some fruit picking, seasonal work. (Daria/'85)

However, for some respondents, working during secondary education was very meaningful as they personally experienced the hardships of labour for the first time. The teenagers started to realise how much time (understood as a resource) is spent at work in order for it to be profitable. They also start to understand that they had many years of "paying their dues" ahead of them if they ever wanted to reach the desired remuneration level:

I worked for the first time when I was 15 or 16 years old. We distributed newspapers in the countryside. I worked for 13 hours to get 50 zlotys. Then I told myself, "I'll be damned! You need to work so hard to earn any money!" When I got that 50 zlotys, it was something amazing. (Maks/'87)

Dedication to the performed tasks had a pivotal significance for evaluating whether work was indeed "a job" (something important and relevant) or just an activity (forgettable, irrelevant). Crucially, serious work was always tied to earning money outside of the family realm:

Never got cash for maintaining my aunt's garden. I had to go [elsewhere], earn money from someone I did not know. (Alan/'92)

To sum up, working during high-school was mostly either seasonal or parttime for the interviewees. The youngsters mostly worked during the summer and the jobs varied in terms of the imprint it left on the biographies. On the one hand, we saw a certain mismatch between these early-on experiences and the image that the respondents, already well on their way up the professional career ladder, wanted to convey. On the other hand, these first experiences were tough lessons in humility, as the interviewees realised the challenges of work, especially when they could not count on family resources.

\section{WORKING WHILE AT UNIVERSITY: BETWEEN SURVIVAL AND COMFORT}

For nearly all respondents, starting university necessitated moving away from home and starting life in a new city. A catalogue of needs, which previously mainly encompassed funding leisure time and vacation travels, was expanded by more basic shortages with regard to the money needed to supplement living costs. At this stage, work becomes professionalised and ascribed with more importance: 
Every paid job is serious. (...) I do it for the money. I am not being impulsive; I need to eat and pay the rent. (Alan/'92)

As this narrative shows, economic motivations impacted on the perception of jobs held while at university. The interviewees also underlined that having a job while studying was much more normalised among their peers. The passage of time plays a key role: while working during high-school was somewhat abnormal, those who did not work at all during their time at university were suddenly judged as either spoiled or slacking. In other words, small-town youths saw avoiding economic activity during university studies as an aberration. The processes linked to the professionalisation of work speed up during this life phase. Again, working and studying takes up much time, and often meant a conflation of university in relation to how it was situated on the temporal plane:

I started work then, having already worked in a restaurant during my summer holidays. Every weekend I worked, so university studies for me went by really quickly. (Ala/'84)

Concurring with Kasparek and Magierowski [2014], we observe that jobs held during university had little to do with the future professions of the respondents. The precarious conditions on the labour market were largely accepted as the interviewees did not strive to go beyond low-level work. Physical and manual labour was also common for those who decided to take part in the post-2004 EU accession migration:

I would not be able to live off working only in the supermarket [during term-time]. [Migration] was a big cash injection. You go there to survive, not to party. I took as many hours as I could to work to the breaking point for two months and then brought back as much cash as possible. (...) If I have a tough month [back in Poland], if I don't go to work or I get sick, then this money will help me stay afloat. I haven't taken any money from my mother for a few years [and I actually] gave her some for Christmas. (Alan/'92)

It is very telling that going abroad had an explicit economic objective but also, hidden in the background, there was a dedication to studying which could potentially have been interrupted without the financial cushion secured by migration money. Another interviewee said:

even my first job [abroad] was a serious one because it gave me tangible money and facilitated the fulfilment of educational plans. (Ela/'87)

A deeper analysis shows that the comfort of studying hard during strenuous periods of academic work hinged upon participating in summer work abroad. 
However, from a career perspective, working abroad was usually played down by the respondents, unless it enabled them to acquire transferable skills:

I don't think [going] to Italy gave me anything professionally. It meant money, and that was cool because I could have savings, and going away for a month was a massive influx of cash on a student budget. Work-wise, it did not mean anything. It was, simply put, working in a field. By contrast, working in London [meant] that I learned English quite well. (Iza/'90)

It is consistent across the interviews that work during the pursuit of higher education never became a priority but rather was conceived more as a type of resource that makes education possible or easier. The arguments for migration were mainly about the "fast money" that the respondents could earn abroad in this "high-cost - high-gain" scenario of not having a summer break but accumulating financial capital ${ }^{4}$. In a way, seasonal work was "an infusion", locked into a very short and intense period. Conversely, work during term-time was "diffused", though it had comparable effects in terms of monetary gains. In this context, we also observed cohort effects. On the one hand, for some youngsters, 2004 coincided with high-school graduation and having 3-month vacations every year due to term planning, so migration became a financially highly viable option for this group. On the other hand, mobility became a normalised form of supplementing income for Polish students more generally.

Considerations around students' perceptions of work again cannot overlook the importance of time in the unfolding educational and career path. As already hinted at above, the respondents clearly prioritised "time for learning" over "time for work" during their university years:

Earlier, it was more about just having some extra money on the side. I did not treat working at the cinema as having a job. I simply reconciled it with university. (Marek/'88)

In accordance with the notion of "flexible time", university students do not calculate how many hours they actually dedicated to working because earning money was not their primary activity in terms of significance. In other words, even those for whom employment was a sine qua non condition for studying (due to economic pressures caused by the absence of parental financial support),

4 More on the interplay between migration and education-to-work transitions can be found in Sarnowska [2016]. In brief, migration had varied importance for the topic of understanding work during the three discussed stages, ranging from having a very positive, through neutral, to negative impact. 
defined themselves as students and not as workers during this life-phase. This understanding also transpired when other professional activities, like internships, were discussed. Though they were conceived as routes to increasing chances on the labour market, they were treated more as a part of education and were again downplayed from the standpoint of a professional career:

I look at the internship as more of a student thing, not serious employment. (Jadzia/'98)

This assessment is of course connected to the fact that internships were commonly unpaid:

I then had an internship at company $X$, but this was not for money, so it does not count, and you are probably not interested in this. (Ela/'87)

Because university is understood as a time for studying, the respondents did not protest when they were given non-standard work contracts. This was also seen as better in terms of actual income as higher net earnings were associated with taxation on such contracts:

When I was a student, it was beneficial for me to work on junk employment contracts. Half of Poland believed that. (Kacper/'92)

For many interviewees, the critical moment came when they turned 26, as this marks the end of taxation benefits. This is somewhat of a social and temporal break, since it signifies that one can no longer rely on temporary and non-standard jobs, and instead must focus on searching for more permanent and standardcontractual employment.

Entering the labour market has a normative sequence evident from social expectations that call for a certain level of experience at a given moment on one's temporal, biographical axis. In this context, even when working during studies was not a priority, undergoing the process of interviewing for jobs is seen as indispensable experience:

I finally decided to go for a different job, which meant going to my first-ever job interview. I was 24 when I had my first interview! All my friends went through that when they were students and were working, but I was a protected underling. (Maks/'87)

The quotation above illustrates how Maks' pace of transitioning from education-to-work was slower than that of his peers. As a consequence, he was slightly behind. The statement from Nadia presented next demonstrates the 
opposite end of the spectrum, when the interviewee experienced an unexpectedly hurried transition:

I would say that getting a standard job contract when I was in my $5^{\text {th }}$ year of uni was met with a "wow" reaction from my friends, I mean the fact I was in my $5^{\text {th }}$ year and had an unlimited contract. This never happens. (Nadia/'88)

As already argued, civil law contracts became a social norm of employment for the studying respondents. Accordingly, getting a standard contract during education was seen as atypical for the preordained order of transitions from education-to-work. The unfavourable labour market conditions in Poland at that time, exemplified by very high unemployment rates for graduates on the eve of accession to the EU, for instance, and later the implications of the global financial crisis, shaped the "historical time". Young people had to operate in the context of flexibilisation and precarisation, and the acquisition of a standard, unlimited work contract became somewhat of a "Holy Grail", with subsequent cohorts socialised to expect poor structural conditions.

\section{WORKING AFTER GRADUATION: FORGING ONE'S PROFESSIONAL PATH TOWARDS STABILITY?}

There is a discernible change in young people's thinking about work at the moment they complete tertiary education. Having a diploma in their hands alters their perception of what should be prioritised, and employment replaces studying as the key activity. This also means that graduates become more selective and seek employment that is congruent with the occupation and specialisation attained through university education. It can be argued that this belongs to a sense of social pressure and awareness of social expectations about professional careers [Settersten 2004; Kohli 2007; Hofmeister 2013].

For most interviewees, a clear understanding of the labour market does not even exist prior to them officially leaving education. However, as graduates, young people start to recognise the gaps between university education and the demands of the labour market that surrounds them. In some cases, it turns out to be difficult to stay afloat without experience:

Unfortunately, university did not prepare us for [the labour market], it was not talked about, and it was like a punch in the gut for us that having a title actually does not bring us anything at all. Experience is what counts. (Maks/'87) 
At the same time, young people start to soft-pedal earlier work experiences that do not match their ideal visions of a future job tied to education:

Working at a fitness club was important, but the job I had at an office was the serious one. I was thinking that, since I had graduated, I should have some sort of serious job, and fitness does not really sound like something serious. (Iza/'90)

Besides underscoring that employment after graduation should be seen as a natural extension and progress built upon the knowledge gained at the university, the research participants also reflected on the duties that were inscribed in their contracts. The key arena seems to revolve around the scope of responsibility, which they believe must grow after graduating.

The respondents felt that graduation also equals new responsibility: as they no longer thought it appropriate to rely on parental support, they rephrased their demands towards employment and work was granted a new function:

When I used to have a more difficult moment [work-wise], I was young enough not to worry too much about things like work or money in general. These held very little importance. It was more important to gain experience, learn new things. Now it is different, of course, because I am at a different moment of my life. (Radek/'83)

Adam's [1998] "flexible time" concepts seem to be at play in the stories. They not only influence the way of thinking and reflections, but actually determine which actions on the labour market are acceptable at certain points. For example, Radek was not concerned about spending a lot of time on experience without pay because the flexible understanding of time at university contracted these years in the timeline of the work-arena, foregrounding time spent on educational rather than occupational activities. Conversely, being over 30 means that "drifting" is no longer socially accepted and "the time is now" for professional success. This is even more evident in Jadzia's account:

Ithink I had very low expectations. Changing jobs and starting at company X [simply] depended on the fact that I had an offer, so I was certain that I should take it. Perhaps had I waited... invested a bit more in getting a more typical job in some super-workplace, then it is absolutely possible that I would have gotten it. Yet, somehow, my attitude was that I have not been demanding in life, I just wanted to have any sort of job and last as long as I could in that position. Though it might sound terrible, that is, well, that is how it was [back then]. (Jadzia/'98)

It seems that Jadzia was not at all selective about reviewing job offers due to being used to working at a low level as a student. Conversely, entering adulthood, or being on the verge of transitioning from early-to-mid adulthood [Arnett 2011], 
means that young people begin to ponder stability [Furlong, Cartmel 2006]. This issue does not emerge at any earlier stages of the interviewees' biographies, neither in adolescence nor through university. However, in their mid-to-late 20s and early-30s, the interviewees start to think about taking on new social roles that may relate to partnering and parenting (e.g. starting a family) or greater financial obligations (e.g. mortgage payments). In this context, it is interesting to show what young people believe elusive "stability" is.

As we have been arguing, time is the pivotal factor for how work is framed, either in the peripheral or central plane of an individual's biography, and this is not different during the transition from education to employment. The initial, often haphazard and inconsequential experiences on the labour market during university are replaced by limited acceptance of non-standard jobs and a determined quest to end uncertainty. Just a few years ago, having a university degree meant a better chance at acquiring a standard, unlimited job contract and a weakened probability of unemployment. Until 2013, the rate of university degree holders working on an unlimited basis dropped by half, while the proportion of those with junk contracts or on the black market nearly quadrupled (from $11 \%$ to $39 \%$ ), meaning that university graduates became the group most likely to be involved in this type of work. What can also be emphasised is that non-standard employment does not constitute a step towards stability: as many as $55 \%$ of those starting with such a contract ended up realising a "sequence of uncertainty" [Kiersztyn 2015].

In stark opposition to instability, which is tied to employment that is uncertain, unpredictable and risky from the worker's perspective [Kalleberg 2009], young Poles largely equate stability with a standard work agreement. Signing a contract, ideally unlimited in duration, is presented as a remedy to a precarious work situation, which signifies temporariness, low income and limited social and workers' rights [Standing 2015]. As mentioned earlier, the role of the contract increases in value as the next stages of a biography unfold. This is clearly a junction of temporalities: the actual biographical, measurable in years of historical time, comes head-to-head with the social time of expectations and wins:

Being our age, I think having a standard contract means stability. Many people need to take out a mortgage for a flat. And, also, many benefits come from this, for instance, health insurance. This was important for me. I did not want to have non-standard agreements all the time. (Iza/'90)

What we also observe is that there is a continuum of growing needs: the money earned in high-school was "for fun", working during university was about survival, later linked to experience, and it was only at the next level that 
it could be associated with success and growth. As time passes, people who graduated have a newfound appreciation of money as a means of being able to afford passions, hobbies, and certain luxuries. We see, therefore, that redefining stability in an expanded temporal sense encompasses not only the present but also unspecified futures. It can also be assumed that, as time goes by and goals are achieved, yet another definition of stability might emerge. What is more, as expected, the respondents for whom money is the main factor that determines their sense of stability placed the level of remuneration over the type or form of work. Sometimes they consciously decided to remain in the "grey zone" to earn more:

Having a contract means some sort of stability, but it is not full-stability in my opinion. For me earning less with a standard contract is less stable that earning more illegally. [The latter] allows me to put money into savings. (Tadek/'88)

The fact that the interviewees come from medium-sized Polish towns may have something to do with the sense of attachment that the young people initially feel in regard to having a standard, ladder-like career trajectory. This type of professional path was something they had observed for their parents, so they must undergo a transformation towards realising that things have changed. A flexible career model, which is marked by uncertainty and the demands of young people to constantly try to adjust to the changing conditions, is taken as a given [Poławski 2012; Lorey 2015; Mrozowicki 2016]. The normalisation of flexibility may stem from the fact that younger cohorts sometimes have no other experiences to draw upon [Bednarski, Frieske 2012]. With the normalisation of job-hopping and precarity, the interviewees may create alternative framings of stability, such as financial security and wealth, but, just as frequently, they negated stability altogether:

(...) we live in a completely different world. In the past, one could go to the vocational school of the factory, and then it was a forever done-deal that you'd go to work in that factory and stay there for your entire life. It was obvious and connected with stability; you had that certainty that finishing school would bring you a job you could bet your life on. So, today, we still have this model in our head but the times are vastly different, there is no way we can talk about stability (...) around a 9-to-5 job. (Kornel/'88)

A strong generational effect among the Polish youth can be distinguished as the respondents are disenchanted about their trajectories having the potential for stability, even though they may be reminiscent of their parents' paths. The younger the research participants, the more it seems that they have doubts about stability as a defining and definite notion. We can explain this by contextualising the historical time to underline the accompanying circumstances that shape the congruence 
of biographies for people born in a given era [Elder 1994]. For the generation of 20- and 30-year-olds in Poland, this shared generational experience seems to be about instability just as much as about its reverse. The presented accounts attest to the unavoidable need to contextualise work biographies on a temporal plane.

Thus, it should not be surprising that not all interviewees believe in stability as something that even exists and can be achieved. Such convictions may be based on personal and professional experience, but they also broadly mirror the postmodern, uprooted and risky biographies in the global era:

I have learnt that stability is a foggy concept. Stability simply does not exist so I am not trying to find it (...). I used to believe in stability and, probably, like the majority, I thought that a good job with a standard contract and [owning] a flat were signs of stability (...). But I have gone through the wringer and [realised] everything can change overnight. (Maks/'87)

Unlike Maks above, a different group with atypical stability-definitions sees it more positively. Specifically, they phrase it around individual agency and the conviction that they will be able to handle whatever the situation on the labour market confronts them with. Instead of forging paths by revoking and subverting classic definitions of stability, the more self-assured type of thinking suggests feeling anchored or settled in employment. Such narratives of self-confidence were based on the already acquired capital and are exemplified in Kamila's account:

I have a set of skills which will allow me to either continue to keep the position I have now or to find a new job. I am confident about my [skills] (...). I feel my situation is stable not because of an unlimited, life-long contract at $X$-as this is something I do not have - but rather I think that I have skills that make me a valued candidate for the labour market. (Kamila/'86)

Simultaneously, some respondents negated the stabilising function of the standard contract, especially if they had had bad experiences in the labour market.

To sum up, we demonstrated a certain dichotomy or dualism when it comes to whether stability is something that young people strive for. Firstly, they see it as inadvertently tied to the standard job contract which enables privileges and rights. This group exemplifies a social fact that an intergenerational change never encompasses everything in the same manner but affects people with differing socio-demographic characteristics to a varied degree. In other words, while some question or reframe stability, a number of respondents followed the professional paths that matched the traditional ladders climbed by their parents in the past. Secondly, stability may reflect feeling well-positioned financially and, thirdly, it speaks to the shift of focus that now mostly addresses the skills and competencies 
as a means to guarantee stability. In that sense, we can distinguish the relevance of the social, financial and educational capitals that the research participants have been accumulating over the course of their education, noting that capital is intersected not only with the paths themselves, but also with their evaluations over time. As we can see, contemporary young people in Poland by no means constitute a homogeneous group.

On the one hand, the majority of young people still would not mind achieving a stable position. They understand stability in the labour market in a number of different ways, however. On the other hand, past difficult experiences, lower social status of their family of origin and having arts-related careers all seem to contribute to a number of respondents rejecting stability as the notion that should emerge as a trait in their employment paths.

\section{CONCLUSIONS}

This work contributes to the post-modern "liquid" lives argument [Bauman 2013] in relation to the contemporary biographies of young people pursuing higher education. We have demonstrated that qualitative data is indispensable for achieving a deeper and enriched understanding of how people make sense of work during key transitions and over time. It adds reflection and sheds light on the temporal shifts that carry a vast range of interpretations; it also compliments the data that show young people increasingly engage in work during high school and university and experience flexibilisation [Kovacheva 2001], intergenerational change [Wyn, Dwyer 2000; Furlong, Cartmel 2006; Kohli 2007; Côté, Bynner 2008], precarity and a mismatch of skills [Allen, De Weert 2007]. These phenomena affect the lives of young people and, thanks to the narratives, we can better interpret certain trends in terms of the "why" and "how".

Telling stories provides a "means of evaluating the present, re-evaluating the past and anticipating the future" [Letherby 2003: 89] and should be seen as a task of "meaning-making" underpinned by the fact that supplying details of experiences requires people to reflect upon them [Neale 2018]. In that sense, we underscore that time is a crucial explanatory variable [Adam 1998; Neale 2018] to understand why working sometimes is seen as meaningless, although it usually becomes a serious, foregrounded aspect of one's lives at subsequent periods and life-stages. We nuance the broader data by arguing that there are many differences in that, temporally, work is sometimes a choice but it later comprises a social and personal requirement. The social demands of work are additionally differently imposed over time on young people with various social backgrounds. In Table 1 
below, we show the main motivations and meanings of work among young Poles born from 1982 to 1995 and interviewed for the project.

To answer the titular question regarding how the meaning of work changes, we must emphasise the key factors that drive the respondents' interpretations of employment in a temporal setting. First of all, people tend to associate certain lifestages with a given primary social status. Specifically, self-definitions consistently rely on being a student during the university years, even if the interviewees work full-time or have demanding jobs. In other words, reflecting on the physical strain of picking fruit every summer for five years is always contextualised by the conviction that a person was not really a fruit-picker but a university student, fully aware of this "non-work" being temporary. At all life stages that are about education, work is not a priority. Secondly, what makes a job irrelevant is when it is not directly linked to university education. As long as it is a "side project", the respondents see their activities as "background noise" rather that something that will ultimately shape their CVs and career trajectories. Thirdly, and most vitally in connection with time, work experiences can only be seen as significant when they concur with the individual $>$ s current identity and self-perception. If a person has reached mid-adulthood and considers themselves to be an educated, highly-skilled and prosperous professional working in the office, they will not see their seasonal work in a bar as anything worth discussing as a past "job". In the narratives, we commonly observed people downplaying the narratives of employment that did not gel with their current status and position. This means that people's evaluations evolve and must always be viewed as temporally-charged.

TABLE 1. Summary of the meaning of work at various stages of youth

\begin{tabular}{|l|l|l|}
\hline Working during high-school & \multicolumn{1}{|c|}{ Working during university } & \multicolumn{1}{|c|}{ Work after graduation } \\
\hline $\begin{array}{l}\text { Part-time and seasonal work } \\
\text { to fund personal needs and } \\
\text { supplement the allowance } \\
\text { received from parents }\end{array}$ & $\begin{array}{l}\text { Part-time and seasonal work } \\
\text { as a response to increasing } \\
\text { costs of living in a large city, } \\
\text { the wish to become financially } \\
\text { independent, work as a means } \\
\text { to gain experience }\end{array}$ & $\begin{array}{l}\text { Building a professional } \\
\text { path, focus on career } \\
\text { linked to education, } \\
\text { wanting a responsible job, } \\
\text { greater expectations about } \\
\text { remuneration }\end{array}$ \\
\hline \multicolumn{2}{|l}{$\begin{array}{l}\text { Acceptance of temporary, uncertain and precarious jobs } \\
\text { with low salaries. } \\
\text { Non-standard, limited, civil-contract agreements }\end{array}$} & $\begin{array}{l}\text { An expectation of stability } \\
\text { brought by a standard, } \\
\text { unlimited, permanent } \\
\text { and full-time contract } \\
\text { Redefinitions of stability } \\
\text { Negating stability }\end{array}$ \\
\hline
\end{tabular}

Source: authors' own elaboration. 
Having said that, it should be added that flexible social time means that the presented evaluations may change again and the work that the respondents consider serious today may lose its relevance over time. Still, timeframes play a vital role [Neale 2013] because life-priorities (e.g. education) were always presented in the foreground and "diffused" in time. Conversely, flexible time made it possible for side events, which perhaps lasted very long (e.g. going abroad to work for three months every year for five years) to be seen as inconsequential because they felt temporally "condensed". During the educational stages of an individual's biography, that is, through high-school and studies, there are no monumental transitions, so not noticing experiences and pushing them from view is quite typical. Young people mirror social expectations which, for them, should primarily focus on learning, so aberrations do happen, but they do not really alter the person's main status as pupil/student, and can be omitted as such. This is because a life trajectory refers to how an individual conforms to societal standards and structural heterogeneity [Adam 1998].

It is evident that the intergenerational changes in the realm of transitions are radical [Wyn, Dwyer 2000; Furlong, Cartmel 2006; Kohli 2007; Côté, Bynner 2008]. In a way, transitions seemed to simply occur somewhat externally in the past, so the individuals in previous generations simply followed "a beaten path", while the education-to-labour-market entries of today's youth are embedded in the context of rapid and constant revolution. The meaning of the key transition from university-to-work is blurred because it has no singularity and forces people to rethink its main feature, namely stability. We argue that young people face a stability paradox: theoretically, transitions to employment are expected to signify some type of steadiness and permanency, yet in practice this almost never takes place. Depending on the experiences gained over time - also by working early on in adolescence and during university - young people develop and evaluate various definitions of stability.

While some respondents had quite standard paths, reminiscent of those stability-inducing moments that their parents experienced, for the vast majority of the interviewees, time and the subsequent exposure to the labour market challenges "made stability unstable". Still coveted, stability is subject to continuous verification, re-evaluations and questioning. In the personal biographies, time explains the tensions between the individual and the structural, as people seek stability to be able to achieve subsequent markers of adulthood - e.g. starting a family - yet the labour market remains unstable and stability can never be a "sure thing". In a nutshell, the research participants cannot escape the stability 
paradox but must find alternative definitions that can help them to self-anchor in the existing social surroundings.

More broadly, thanks to QLS, observations about the meaning of work can be made through a temporal journey and textured onto a multi-layered understanding of biographies [Neale 2018]. Since we are "walking alongside" the respondents as they are asked to retrospectively discuss their employment histories and describe meanings of stability at subsequent stages of their lives, we are able to present a selection of narratives evidencing the shifts and evaluations. They are embedded on a temporal plane and elucidate the pivotal role of the passage of time [Adam 1998]. Our interviewees are at the key biographical moments of their trajectories, so it is expected that the changes will now develop at a slower pace. This underlines the timeliness of the project, and it can also be linked to the ongoing explorations we are conducting and envisioning around precarity, temporality and social class junction, as well as skills and competencies. Some of these aspects will be explored in Wave 3 of the QLS.

\section{REFERENCES}

Adam Barbara. 1998. Timescapes of modernity: The environment and invisible hazards. London/ New York: Routledge.

Allen Jim, Egbert De Weert. 2007. "What do educational mismatches tell us about skill mismatches? A cross-country analysis". European Journal of Education 42(1): 59-73.

Arnett Jeffrey J. 2011. Adolescence and emerging adulthood. Boston, MA: Pearson.

Bauman Zygmunt. 2013. Liquid modernity. Cambridge: John Wiley and Sons.

Beck Ulrich, Anthony Giddens, Scott Lash. 1994. Reflexive modernization: Politics, tradition and aesthetics in the modern social order. Cambridge: Polity.

Bednarski Marek, Kazimierz Frieske. (eds.). 2012. Zatrudnienie na czas określony w polskiej gospodarce. Społeczne i ekonomiczne konsekwencje zjawiska. Warszawa: IPiSS.

CBOS (Centrum Badania Opinii Społecznej). 2016. "Młodzież 2016”. Opinie i diagnozy 38. Warszawa: CBOS.

Côté James, John M. Bynner. 2008. "Changes in the transition to adulthood in the UK and Canada: The role of structure and agency in emerging adulthood". Journal of Youth Studies 11(3): 251-268.

Elder Glen H. 1994. "Time, human agency, and social change: Perspectives on the life course". Social Psychology Quarterly 57(1): 4-15.

ETUI (European Trade Union Institute). 2015. Benchmarking working Europe 2015. Brussels: ETUI.

Eurostat LFS. n.d. http://ec.europa.eu/eurostat/data/database [access: 19.04.2016].

Furlong Andy, Fred Cartmel. 2006. Young people and social change. London: McGraw-Hill Education.

Geel Regula, Uschi Backes-Gellner. 2012. "Earning while learning: When and how student employment is beneficial". Labour 26(3): 313-340. 
Grabowska Izabela, Paula Pustułka, Natalia Juchniewicz, Justyna Sarnowska, Marta Buler. 2017. "Peer groups and migration. Dialoguing theory and empirical research". Youth Working Papers 5/2017, Warszawa: Młodzi w Centrum Lab.

GUS (Główny Urząd Statystyczny). 2017. Kapitał ludzki w Polsce w latach 2012-2016. http:// stat.gov.pl/obszary-tematyczne/inne-opracowania/inne-opracowania-zbiorcze/kapital-ludzki-w-polsce-w-latach-2012-2016,8,6.html [access: 9.09.2018].

GUS (Glówny Urząd Statystyczny). 2018. Szkolnictwo wyższe w roku akademickim 2017/2018 (dane wstęne). http://stat.gov.pl/obszary-tematyczne/edukacja/edukacja/szkolnictwo-wyzsze-w-roku-akademickim-20172018-dane-wstepne,8,5.html [access: 10.09.2018].

Hofmeister Heather. 2013. "Individualisation of the life course". International Social Science Journal 64(213-214): 279-290.

Holdsworth Clare, David Morgan. 2005. Transitions in context: Leaving home, independence and adulthood: leaving home, independence and adulthood. Glasgow: Open University Press.

Hodkinson Phil, Andrew C. Sparkes, Heather Hodkinson. 2013. Triumphs and tears: Young people, markets, and the transition from school to work. New York: Routledge.

Jelonek Magdalena. 2015. Młodzi na rynku pracy - polityka publiczna wobec wyzwań związanych z poprawą sytuacji zawodowej osób młodych. W: Polski rynek pracy - wyzwania i kierunki działań na podstawie badań Bilans Kapitału Ludzkiego 2010-2015, J. Górniak (eds.), 41-54. Warszawa/Kraków: PARP.

Kalleberg Arne L. 2009. "Precarious work, insecure workers: Employment relations in transition". American Sociological Review 74(1): 1-22.

Kasparek Krzysztof, Mateusz Magierowski. 2014. Kogo kształca polskie szkoty? Na podstawie badań uczniów i analizy kierunków ksztatcenia zrealizowanych w 2013 roku w ramach IV edycji projektu Bilans Kapitału Ludzkiego. Edukacja a rynek pracy - tom III. Warszawa/ Kraków: PARP.

Kiersztyn Anna. 2015. Niepewne uczestnictwo - młodzi na polskim rynku pracy w latach 2008-013: wybrane wyniki Polskiego Badania Panelowego POLPAN 1988-2013. Warszawa: IFiS PAN.

Kohli Martin. 2007. "The institutionalization of the life course: Looking back to look ahead". Research in Human Development 4(3-4): 253-271.

Kovacheva Siyka. 2001. "Flexibilisation of youth transitions in Central and Eastern Europe". Young 9(1): 41-60.

Letherby Gayle. 2003. Feminist research in theory and practice. Buckingham/Philadelphia: Open University Press.

Lorey Isabell. 2015. State of insecurity: Government of the precarious. London/New York: Verso.

Marsh Herbert W. 1991. "Employment during high school: Character building or a subversion of academic goals?" Sociology of Education 64(3): 172-189.

Metcalf Hilary. 2003. "Increasing inequality in higher education: the role of term-time working". Oxford Review of Education 29(3): 315-329.

Mrozowicki Adam. 2016. "Normalisation of precariousness? Biographical experiences of young workers in the flexible forms of employment in Poland". Przeglad Socjologii Jakościowej 12(2): 94-112.

Neale Bren. 2013. "Adding time into the mix: Stakeholder ethics in qualitative longitudinal research”. Methodological Innovations Online 8(2): 6-20.

Neale Bren. 2018. What is qualitative longitudinal research? Oxford: Bloomsbury Academic.

Piróg Danuta. 2016. "Opóźnienia w przechodzeniu absolwentów szkół wyższych na rynek pracy: przyczyny, typologia, następstwa”. Studia Ekonomiczne 292: 144-157. 
Poławski Pawel. 2012. "Precarious generation on the Polish labour market". Polityka Społeczna 1(39): 15-22.

Pustułka Paula, Natalia Juchniewicz, Izabela Grabowska. 2017. "Participant recruitment challenges in researching peer groups and migration retrospectively". Przeglad Socjologii Jakościowej 13(4), 48-69.

Salas-Velasco Manuel. 2007. "The transition from higher education to employment in Europe: The analysis of the time to obtain the first job". Higher Education 54(3): 333-360.

Sarnowska Justyna. 2016. "Double transition: university-to-work abroad and adulthood". Rocznik Lubuski 42(2a), 215-228.

Sarnowska Justyna, Izabela Grabowska. 2018. "Młodzi dorośli łączący studia z pracą studium przypadku absolwentów socjologii i kulturoznawstwa Uniwersytetu SWPS”. Górnoślaskie Studia Socjologiczne. Seria Nowa 9, 47-62.

Settersten Richard. 2004. Age structuring and rhythm of life course. In: Handbook of life course. J.T. Mortimer, M.J. Shanahan (eds.), 81-98. New York: Springer.

Staff Jeremy, Jeylan T. Mortimer. 2007. "Educational and work strategies from adolescence to early adulthood: Consequences for educational attainment”. Social Forces 85(3): 1169-1194.

Standing Guy. 2015. Karta prekariatu. Warszawa: PWN.

Wyn Johanna, Peter Dwyer. 2000. "New patterns of youth transition in education". International Social Science Journal 52(164): 147-159.

\author{
Justyna Sarnowska \\ Dominika Winogrodzka \\ Paula Pustułka
}

\title{
ZMIENIAJĄCE SIĘ ZNACZENIA PRACY WŚRÓD MLODYCH DOROSEYCH Z WYKSZTALCENIEM WYŻSZYM W PERSPEKTYWIE TEMPORALNEJ
}

\section{Streszczenie}

Celem artykułu jest przedstawienie znaczeń, jakie młodzi ludzie nadają pracy wraz z upływem czasu. Skupiamy się na narracjach młodych osób (w wieku 19-34 lata) z wyższym wykształceniem, będących na różnych etapach procesu wchodzenia w dorosłość. Odwołując się do badań dotyczących przechodzenia z edukacji do zatrudnienia, wykorzystujemy koncepcję elastycznego czasu społecznego [Adam 1998], by przedstawić, jak jednostki konstruują zmiany oraz punkty zwrotne w swoich biografiach. Wraz z upływem czasu zmienia się ocena poszczególnych wydarzeń i doświadczeń na rynku pracy. Opierając się na materiale z projektu „Przejścia młodych z edukacji na rodzimy i zagraniczny rynek pracy: rola lokalności, grupy rówieśniczej i nowych mediów", omawiamy różne znaczenia nadawane pracy na trzech etapach życia od późnej adolescencji do wczesnej dorosłości. Przede wszystkim oddajemy głos badanym, którzy podzielili się swoimi refleksjami na temat: (1) pracy w trakcie szkoły średniej, (2) łączenia studiów z praca, (3) wchodzenia na rynek pracy bezpośrednio po zdobyciu wykształcenia uniwersyteckiego oraz na późniejszych etapach trajektorii. Artykuł rzuca światło na kwestię stabilności na rynku pracy i jej konstruowaniu na kolejnych etapach życia.

Słowa kluczowe: młodzi dorośli, znaczenie pracy, wchodzenie w dorosłość, bieg życia, analiza temporalna, rynek pracy 